\title{
Selection of an Experimental Fish Ladder Located at the Dam of the Itaipu Binacional, Paraná river, Brazil
}

\author{
Domingo Rodriguez Fernandez ${ }^{1 *}$, Angelo Antônio Agostinho ${ }^{2}$ and Luis Mauricio Bini ${ }^{3}$ \\ ${ }^{1}$ Itaipu Binacional; Av. Tancredo Neves, 6731; Foz do Iguaçu - PR - Brazil. ${ }^{2}$ Universidade Estadual de Maringá; \\ Av. Colombo, 5790; Maringá - PR - Brazil. ${ }^{3}$ Departamento de Biologia Geral; ICB; Universidade Federal de \\ Goiás; Goiás - GO - Brazil
}

\begin{abstract}
The specific selection of a weir and orifice type experimental fish ladder in the dam of the Itaipu Reservoir (Paraná River) was evaluated by samplings in the river downstream and at two points along the ladder (at heights of $10 \mathrm{~m}$ and $27 \mathrm{~m}$ ) during 28 months. Among the 65 species recorded in the river (immediate downstream of the dam), 27 were captured on the ladder. The species that showed highest density on the ladder, the majority migratory, were moderately, or only slightly, abundant downstream. Among the most abundant species downstream, only one, nonmigratory, was recorded in the ladder. The structure presented a negative selection in relation to large migratory pimelodids that might be overcome by enlarging the scale of its design. The sampling demonstrated a moderate selection of species along the ladder and its hydraulic model proved satisfactory regarding the attraction and efficient ascent of the fishes.
\end{abstract}

Key words: Fish ladder, fish migration, selectivity, fish transposition, reservoir

\section{INTRODUCTION}

With the formation of the Itaipu Reservoir in October 1982, the natural barrier to the migration of rheophylic fishes of the middle reaches of the Paraná River (Sete Quedas falls) was replaced by the artificial barrier of the Itaipu hydroelectric dam, located $170 \mathrm{~km}$ downstream. Reproductive activity of the fish assemblages that are concentrated in the first kilometers downstream of the Itaipu dam has progressively decreased, especially the large sized species, more important to the fishery (Agostinho, 1993). As a solution to this problem, the construction of ladders for the ascent of fishes has been suggested, thus providing continuity to their migration. However, there are no studies on the efficiency of large-size ladders for the transposition of neotropical fishes. Except for the preliminary results obtained by Itaipu Binacional (Borghetti, 1993), the capability of the fishes in the Paraná River to overcome the obstacles interposed by the height, flow or design of the transposition structures of the dams is still unknown. The absence of consistent information is also responsible for the controversy about this theme (Britski, 1994).

To analyze the factors relating to the attraction and ascension of the potamodromous species of the middle Paraná, it was implanted an experimental project (Fish Migration Channel Project) downstream from the Itaipu hydroelectric power plant. The evaluation of the fish ladder selection, using population (reproductive and trophic aspects) and community variates (species

\footnotetext{
* Author for correspondence
} 
abundance and diversity) is important to support the correct management of the fish transposition structures in dams (Fernandez, 1996).

The present work compares the specific compositions and the relative abundances of fishes in samples obtained from two regions of an experimental ladder. The selection of the species that enter the ladder, in relation to the assemblage of fishes that inhabit the course of the Paraná River immediately below, was also evaluated. The differences verified in composition and abundance are taken as indicative of this selection.

\section{MATERIALS AND METHODS}

The fish ladder analyzed is part of the structure conceived by the Environmental and Engineering areas of Itaipu Binacional, within the experimental project of the Fish Migration Channel. It is located downstream of the dam of the Itaipu power plant, beside the tailrace of the $15^{\text {th }}$ turbo-generator unit, and is devoted to research on factors related to the attraction and migration dynamics of the potamodromous species of the Middle Paraná.

The ladder possesses a mean difference in levels of 27 meters and a length of 155 meters, containing step-tanks measuring $1.8 \times 1.4 \times 1.0$ meters. Each step has surface orifices $(0.30 \times 0.40$ $\mathrm{m})$ and bottom orifices $(0.30 \times 0.60 \mathrm{~m})$ in opposed positions and triangular speed reducers $(5 \mathrm{~cm}$ in height) set parallel to each other on the bottom. During the study, the discharge was 334 liters per second and the water velocity was 2.2 meters per second. Below the dam, the average discharge was 11,943 cubic meters per second. Samples of fishes were taken monthly from November 1994 to February 1997, at two points on the fish ladder. The first point was located in the second stillwater rest pond on the ladder, at 40 meters from its base and at a height of $10 \mathrm{~m}$ above the mean elevation of the Paraná River, designated as Box A. The second one, Box $B$, is located in the fourth rest pond, at the end of the ladder, at $155 \mathrm{~m}$ from the base and $27 \mathrm{~m}$ in height.

The samples were obtained with hand nets equipped with meshes of 5 and $15 \mathrm{~mm}$, that were operated during 1 and 3 minutes, respectively. In addition, samples were taken every three months during 1997, employing fixed nets with meshes of 2.4 to $16 \mathrm{~cm}$, as well as from trotlines set in the stretch downstream from the ladder.
The species richness in the ladder rest ponds and downstream was estimated by means of the index proposed by Chao (1987). It is a non-parametric index that only employs presence/absence data, calculated by means of the following formula:

$$
S_{\text {Chao }}=S_{o b s}+\frac{Q_{1}^{2}}{2 Q_{2}}
$$

where $S_{o b s}$ is the total number of species observed in all the months of collection and $Q_{1}$ and $Q_{2}$ are the number of species caught in a single month, and in exactly two months, of collection, respectively.

The differences between the estimates and the species richness downstream of the Itaipu Reservoir indicates with greater precision the magnitude of the fish ladder selection, since the use of the index, contrary to the observed values, can minimize problems of insufficient sampling. The patterns of similarity among the observations (downstream, Box A and B) were summarized by means of a Detrended Correspondence Analysis (DCA; Hill and Gauch, 1980). The abundance of fishes sampled on the ladder and in the downstream stretch was expressed as a percentage of the total sampled at each location.

In the comparison between the results obtained in the ladder and downstream, it is necessary to emphasize that the sample periods were not the same. However, given the sharp differences that were detected (see Figs. 1 and 2), the overall conclusions may be considered robust to temporal variations in fish assemblage structure below the dam. In other words, marked temporal variations in the fish assemblage that could occur would not invalidate the main conclusions of this paper. Besides, long term data (8 years) obtained below the dam indicate that 1998 was a typical year in terms of species composition and relative abundance patterns (Agostinho et al., 1999).

\section{RESULTS}

The total number of individuals $(>10 \mathrm{~cm}$ standard length) was 1461 of which $44.3 \%$ came from the Box $B$. For those of small size (below $10 \mathrm{~cm}$ ) this number reached 18,574 individuals, of which $36.5 \%$ were from the Box B. In the area downstream of the ladder, the sampling carried out 
in four months (March, June, September and December of 1997) resulted in the capture of 1,835 individuals belonging to sixty-five species. Twenty-seven species $(41.9 \%$ of those captured downstream) were recorded on the ladder (Table1).

Among the five most abundant species downstream, only Schizodon borelli was recorded on the ladder. The six most abundant species and with the greatest frequency of occurrence on the ladder presented a moderate relative abundance downstream, except for Leporinus friderici, less abundant and Bryconamericus stramineus, a small-sized species not caught with the fishing gears employed downstream. On the other hand, two rare species downstream (Acestrorhynchus lacustris, Sorubim lima) presented a moderate frequency on the ladder (Table 1).

Table 1. Species sampled, relative abundance and frequency of occurrence (months) on the ladder (Box A and Box B) and in the area below (Downstream). [Abundance in relation to the total captures at the location: $+++=$ high $(>5 \%),++=$ moderate $(<5 \%$ and $>0.5 \%),+=$ low $(<0.5 \%$ and $>0.05 \%), \mathrm{R}=$ rare $(>0.005 \%),-=$ absent; $*=$ no data available; numbers between brackets $=\%$ of individuals in relation to the total recorded on the ladder]. Codes $=$ indicate species codes used in Fig. 3.

\begin{tabular}{|c|c|c|c|c|c|c|}
\hline \multirow{2}{*}{ Species } & \multirow{2}{*}{ Codes } & \multicolumn{2}{|c|}{ Box A } & \multicolumn{2}{|c|}{ Box B } & \multirow{2}{*}{$\begin{array}{c}\text { Downstream } \\
\text { Abundance }\end{array}$} \\
\hline & & Abundance & Occurrence & Abundance & Occurrence & \\
\hline Hemisorubim platyrhynchos & 15 & + & 2 & - & - & ++ \\
\hline Astyanax fasciatus & 57 & $\mathrm{R}$ & 1 & - & - & $\mathrm{R}$ \\
\hline Leporinus sp. & 63 & + & 1 & - & - & $\mathrm{R}$ \\
\hline Astyanax sp. & 61 & + & 1 & - & - & $*$ \\
\hline Bryconamericus stramineus & 56 & +++ & $24(63,5)$ & +++ & $25(36,5)$ & $*$ \\
\hline Astyanax asuncionensis & 2 & +++ & $23(45,2)$ & +++ & $20(54,8)$ & ++ \\
\hline Leporinus friderici & 20 & +++ & $23(45,4)$ & +++ & $16(54,6)$ & + \\
\hline Leporinus elongatus & 19 & +++ & $21(69,0)$ & +++ & $15(31,0)$ & ++ \\
\hline Prochilodus lineatus & 34 & +++ & $19(62,8)$ & +++ & $16(37,2)$ & ++ \\
\hline Pimelodus maculatus & 35 & ++ & $10(28,6)$ & +++ & $8(71,4)$ & ++ \\
\hline Leporellus vittatus & 24 & ++ & 6 & + & 2 & ++ \\
\hline Acestrorhynchus lacustris & 62 & ++ & 5 & ++ & 4 & $\mathrm{R}$ \\
\hline Cheirodon sp. & 59 & + & 5 & + & 3 & $*$ \\
\hline Pterodoras granulosus & 33 & ++ & 5 & ++ & 4 & ++ \\
\hline Schizodon borelli & 47 & ++ & 5 & ++ & 4 & +++ \\
\hline Apareiodon affinis & 1 & ++ & 4 & ++ & 2 & ++ \\
\hline Pimelodus ornatus & 36 & ++ & 4 & ++ & 4 & + \\
\hline Sorubim lima & 49 & + & 4 & ++ & 1 & $\mathrm{R}$ \\
\hline Hypostomus sp. & 17 & ++ & 3 & ++ & 4 & ++ \\
\hline Iheringichthys labrosus & 18 & + & 1 & + & 2 & + \\
\hline Odontostilbe microcephala & 58 & $\mathrm{R}$ & 1 & $\mathrm{R}$ & 2 & $*$ \\
\hline Salminus maxillosus & 51 & + & 1 & + & 1 & ++ \\
\hline Characidium sp. & 60 & - & - & $\mathrm{R}$ & 1 & $*$ \\
\hline Megalancistrus aculeatus & 65 & - & - & + & 1 & $\mathrm{R}$ \\
\hline Oxydoras knerii & 64 & - & - & + & 1 & $\mathrm{R}$ \\
\hline Pseudopimelodus zungaro & 40 & - & - & ++ & 2 & $\mathrm{R}$ \\
\hline Roeboides paranensis & 44 & - & - & + & 1 & $\mathrm{R}$ \\
\hline Auchenipterus osteomistax & 4 & - & - & - & - & +++ \\
\hline Lycengraulis olidus & 22 & - & - & - & - & +++ \\
\hline Potamorhina squamoralevis & 38 & - & - & - & - & +++ \\
\hline Rhaphiodon vulpinus & 46 & - & - & - & - & +++ \\
\hline Galeocharax knerii & 12 & - & - & - & - & ++ \\
\hline Hemiodus orthonops & 14 & - & - & - & - & ++ \\
\hline Hypostomus ternetzi & 16 & - & - & - & - & ++ \\
\hline Leporinus striatus & 23 & - & - & - & - & ++ \\
\hline Moenkhausia intermedia & 25 & - & - & - & - & ++ \\
\hline Pseudoplatystoma corruscans & 30 & - & - & - & - & ++ \\
\hline Parauchenipterus galeatus & 32 & - & - & - & - & ++ \\
\hline Plagioscion squamosissimus & 39 & - & - & - & - & ++ \\
\hline
\end{tabular}


Cont. Table 1

\begin{tabular}{|c|c|c|c|c|c|c|}
\hline Serrasalmus marginatus & 50 & - & - & - & - & ++ \\
\hline Schizodon platae & 53 & - & - & - & - & ++ \\
\hline Abramites hypselonotus & 3 & - & - & - & - & + \\
\hline Brycon orbignyanus & 7 & - & - & - & - & + \\
\hline Cynopotamus amazonus & 8 & - & - & - & - & + \\
\hline Catathyridium jenynsii & 9 & - & - & - & - & + \\
\hline Crenicichla nierderleinii & 10 & - & - & - & - & + \\
\hline Eigenmannia sp. & 11 & - & - & - & - & + \\
\hline Leporinus octofasciatus & 21 & - & - & - & - & + \\
\hline Pachyurus bonariensis & 28 & - & - & - & - & + \\
\hline Pseudoplatystoma fasciatum & 31 & - & - & - & - & + \\
\hline Pimelodella sp. & 41 & - & - & - & - & + \\
\hline Potamotrygon sp. & 42 & - & - & - & - & + \\
\hline Pinirampus pirinampu & 37 & - & - & - & - & + \\
\hline Tetragonopterus argenteus & 54 & - & - & - & - & + \\
\hline Trachydoras paraguayensis & 55 & - & - & - & - & + \\
\hline Ageneiosus ucayalensis & 5 & - & - & - & - & $\mathrm{R}$ \\
\hline Brycon microlepis & 6 & - & - & - & - & $\mathrm{R}$ \\
\hline Hypophthalmus edentatus & 13 & - & - & - & - & $\mathrm{R}$ \\
\hline Metynnis sp. & 26 & - & - & - & - & $\mathrm{R}$ \\
\hline Psectrogaster curviventris & 29 & - & - & - & - & $\mathrm{R}$ \\
\hline Pimelodus fur & 27 & - & - & - & - & $\mathrm{R}$ \\
\hline Roeboides bonariensis & 43 & - & - & - & - & $\mathrm{R}$ \\
\hline Roeboides prognatus & 45 & - & - & - & - & $\mathrm{R}$ \\
\hline Steindachnerina insculpta & 48 & - & - & - & - & $\mathrm{R}$ \\
\hline Serrasalmus nattereri & 52 & - & - & - & - & $\mathrm{R}$ \\
\hline
\end{tabular}

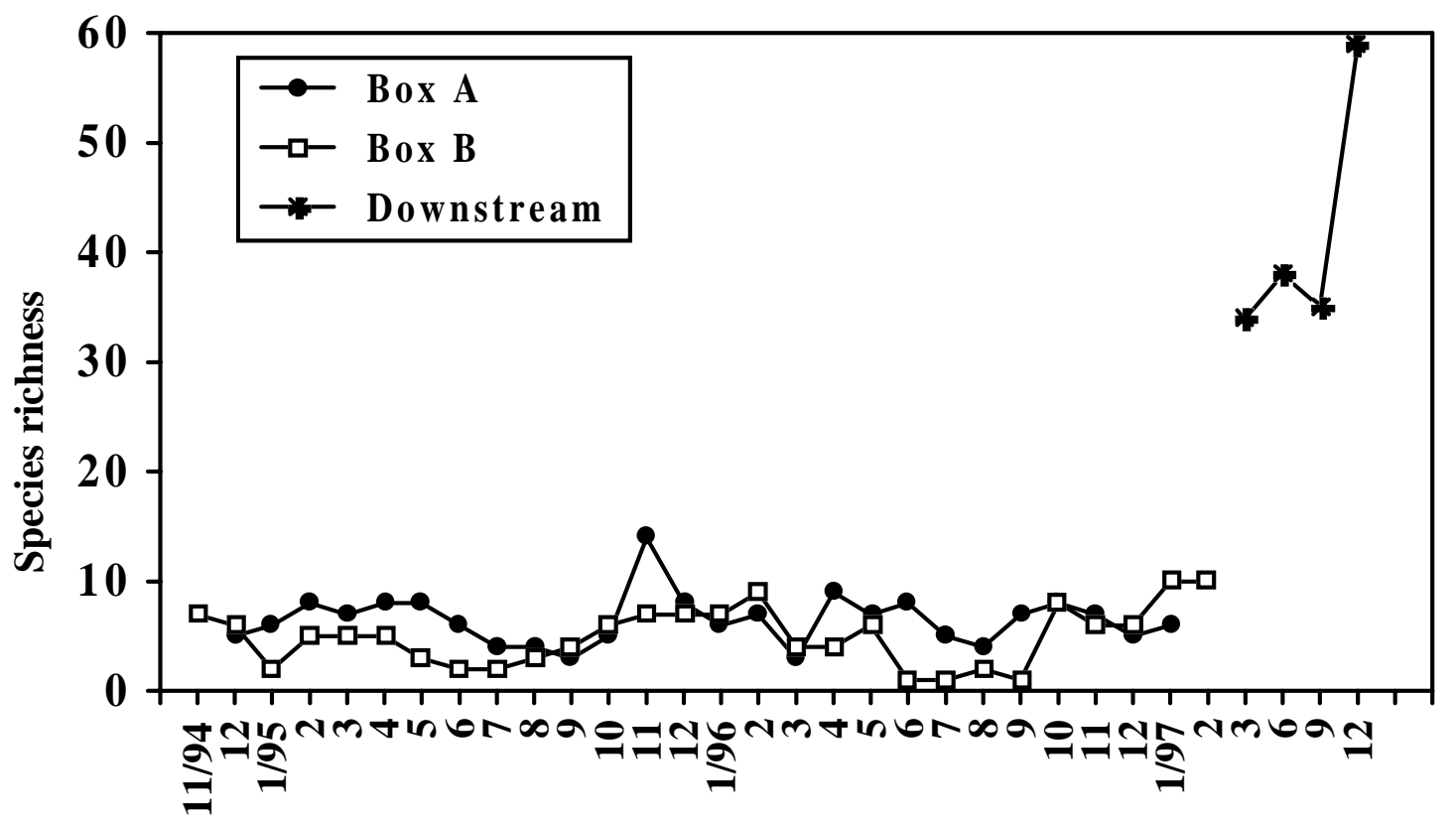

Month/Year

Figure 1 - Monthly variation of the species richness (number of species) on the fish ladder and stretch of the Paraná river, downstream from the Itaipu dam. 


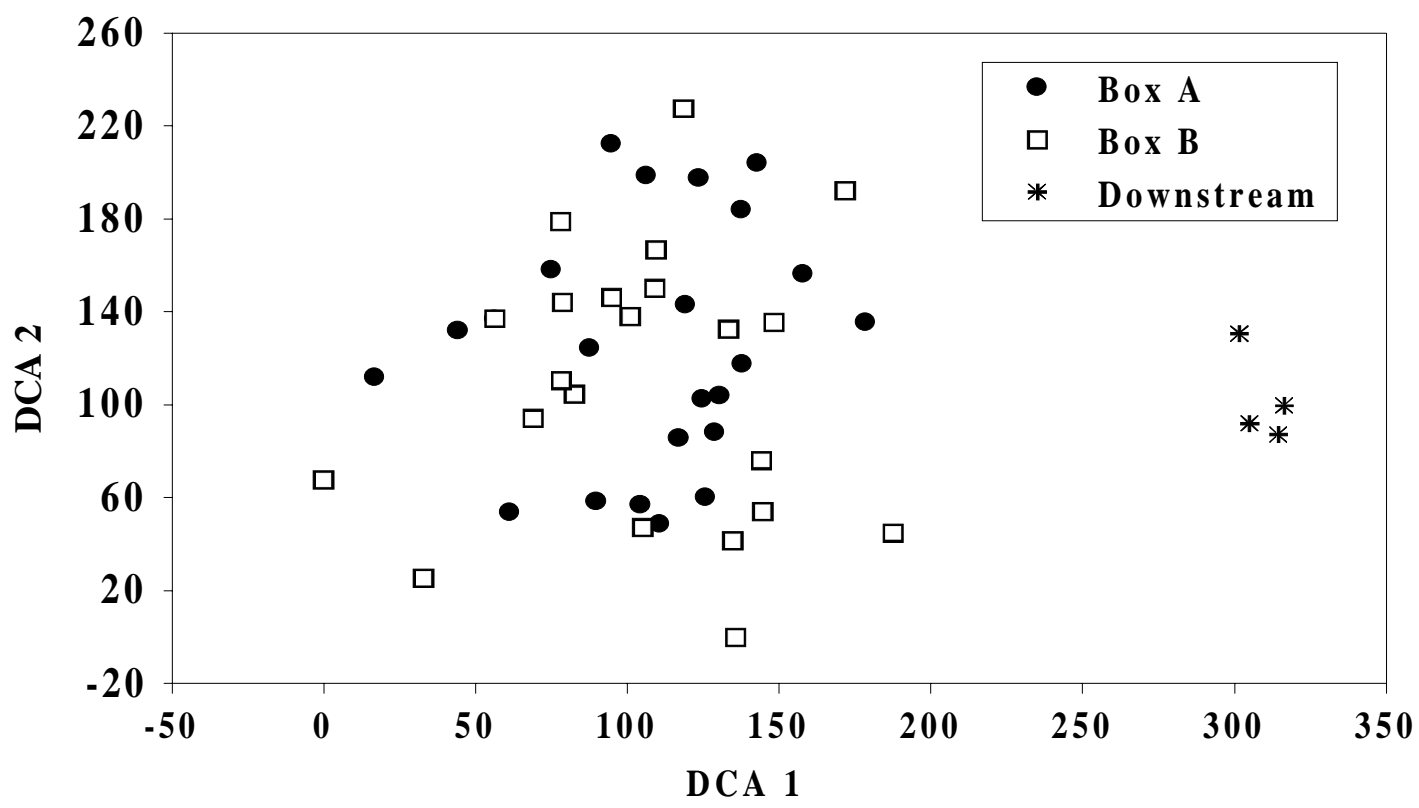

Figure 2 - Scores of samples along the first two axes derived from detrended correspondence analysis.

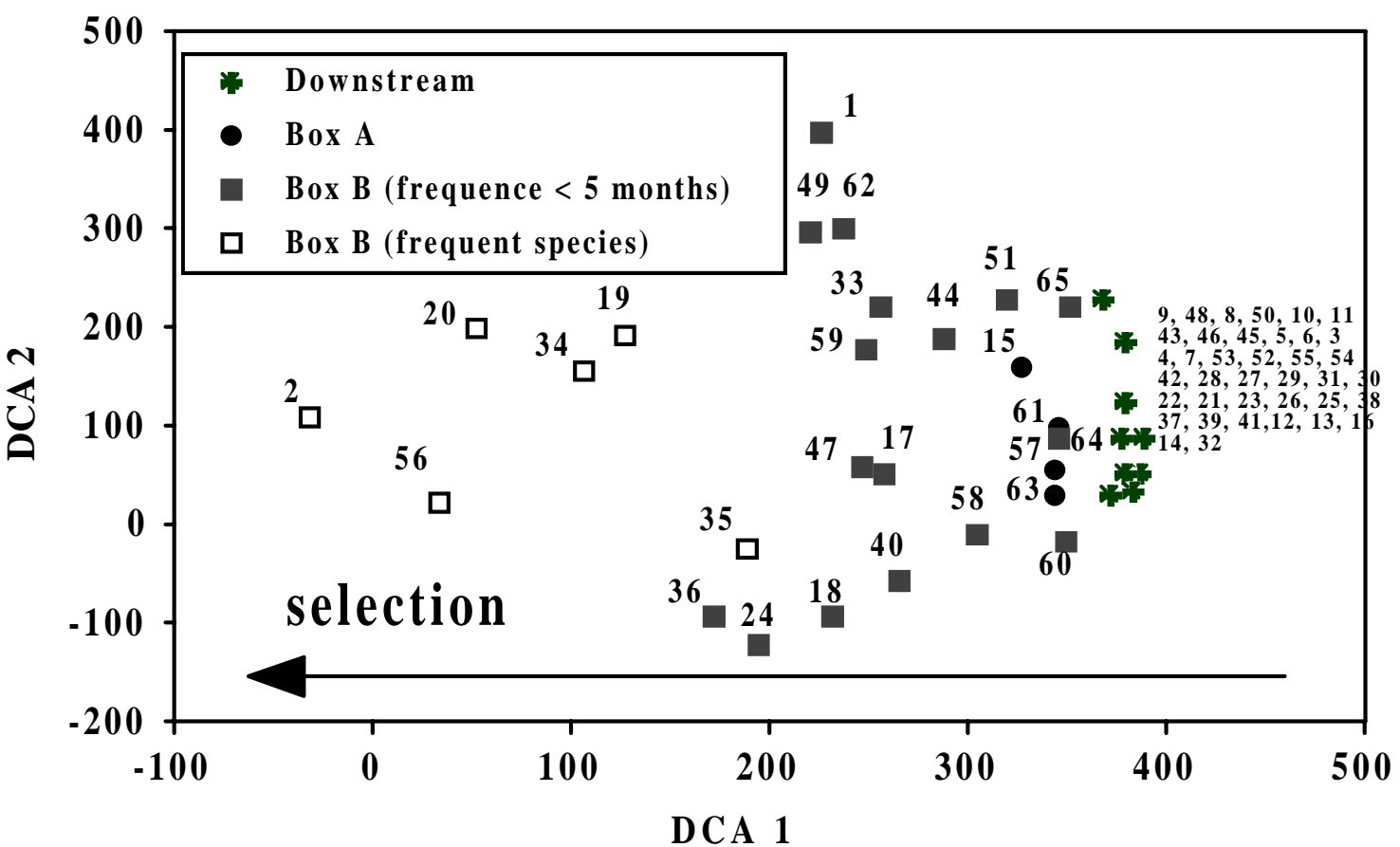

Figure 3 - Species scores along the first two axes derived from detrended correspondence analysis (see species codes in Table 1. 
Table 2 - Number of species observed $\left(S_{\text {obs }}\right)$ and the estimated total (Chao index, $S^{*}$ ) at (Box A) and (Box B) of the Itaipu Binacional experimental fish ladder. $(\mathrm{N}=$ number of samples, $\mathrm{DP}=$ standard deviation $)$.

\begin{tabular}{lc|c|r|r|r|r|c}
\hline & $\mathbf{N}$ & $\mathbf{S}_{\text {obs }}$ & Mean & Minimum & Maximum & SD & $\left(\mathbf{S}^{*}\right)$ \\
\hline Box A & 26 & 22 & 6.5 & 3 & 14 & 2.3 & 31 \\
Box B & 26 & 23 & 5 & 1 & 10 & 2.5 & 28 \\
Downstream & 4 & 65 & 41.5 & 34 & 59 & 12 & \\
\hline
\end{tabular}

The species richness observed at the sampling points of the ladder, throughout all the months of collection, was approximately four times less than the species richness downstream, considering the samples obtained in the subsequent period (Fig. 1). Even after the use of estimated values (Chao index), which indicates the number of species expected for a greater number of samples, it can be observed that more than half the potential pool of species, i.e., the species present downstream, is not captured at the ladder sampling points (Table 2).

Detrended correspondence analysis indicates that the specific compositions of Boxes A and B are fairly similar (Fig. 2). All the species captured in the fish ladder were also captured downstream of the Itaipu reservoir (Table 1). Hence, the large separation observed between the samples obtained downstream of the reservoir and the samples obtained in the fish ladder also reflects the differences in the species richness (Fig. 3). The scores of the species indicate, however, that only the most abundant species in the Paraná River, downstream of the Itaipu Reservoir, are capable of reaching the fish ladder with a high monthly frequency (Table 1).

\section{DISCUSSION}

The efficiency of the fish transposition mechanisms in dams depends on the peculiarities of the ichthyofauna downstream, particularly those related to the migration capacity and the rheophylia. Even low obstacles $(40 \mathrm{~cm})$ revealed as highly selective, depending on the characteristics of the local fauna (Peter, 1998). However, even in assemblages which a great number of species is able to ascent, factors such as the location of the access to the ladder, its attraction capacity and the local water circulation patterns downstream are critical for the process to occur, and can determine high selectivity.

In the case of the entrance not being soon recognized, the fishes may remain in its vicinity for a long time, delaying the migration and compromising the spawning, or even totally impeding access to it (Agostinho et al., 2002). This factor is worsened by the stress provoked by the unnatural environmental conditions immediately downstream of the dam, specially those related to the temperature, water velocity and water quality (Clay, 1995).

In the High Paraná River, close to $21.0 \%$ of the species are classified as large distance migrant which, added to those that undertake small migrations, reaches a percentage of $34.4 \%$ of the fish fauna (Agostinho et al., 2000). Using as a reference the classification of the species according to reproductive strategy done by Agostinho et al (2000), it is found that downstream of the Itaipu dam, close to $28 \%$ of the species recorded can be considered as long-distance migrants which, added to the short-distance migrants, corresponds to $60 \%$ of the total. Upon the experimental fish ladder tested, where $42 \%$ of the 65 species present in the stretch immediately downstream of the dam were recorded, the nonmigrants contributed nearly $36 \%$ of the species recorded. The efficiency in the location of the ladder and its entrance was more pronounced among the migrants $(60 \%$ of the species in the downstream stretch) than among the non-migrants (28\%). In the hydro power plant of the Tijuco River, High Paraná, the fish ladder attracted 34 of the 41 species present (Godinho et al., 1991). Problems with the location of the entry to the ladders have been pointed out as responsible for the inefficiency of many of these structures in different continents (Quirós, 1988; Larinier, 1998; Williams, 1998; Oldani et al. submitted). Schwalme (1985) tested the efficiency of three fish ladders (one of the type with step-tanks and two of the Denil type, with declines between 10 and 20\%) for non-salmonid species in the Lesser Slave River, reported that although thousands of individuals of the rheophylic species ascended the ladders, some species of this group did not use them.

The non-migratory species that are successful in locating and entering the ladder are, in general, 
those of reduced size and that normally inhabit running waters (Characidium, Astyanax, Bryconamericus). A monitoring carried out in the fish passage of the Tailfer dam, in the Meuse River (Belgium), revealed that $93.4 \%$ of the total of the samples were non-rheophylic species (Haro, 1999).

The absence of some large distance migrants (Brycon orbignyanus, B. microlepis, Pseudoplatystoma fasciatum, Pinirampus pirinampu, and Pimelodus fur) in the ladder may be due to their low frequency in the downstream stretch. The restrictions imposed on the size or the height of the fishes by the dimensions of the surface and bottom orifices in the walls separating the tanks on this type of ladder explain the absence of Pseudoplatystoma corruscans and Rhaphiodon vulpinus and have been mentioned by Borghetti et al. (1993) and Agostinho et al. (2002).

The ladder design and the associated hydraulic regime constitute fundamental factors for the ascent of fishes; being responsible for a large part of the selection imposed by these facilities (Clay, 1993). Martins (2000), in testing five ladder designs among those most frequently utilized, concluded that the type of ladder of this study was one of the most promising, due to permitting an adequate control over the speed and the flow, one of the most effective coefficients of energy dissipation, with defined flow-lines. Absence of recirculations and compromising vortexes, thus minimizing the disorientation of fishes. In addition, this design presented a structurally simpler concept.

In general, the samplings at two points of the fish ladder (Boxes A and B) demonstrated low specific selectivity along the ladder during the period. Out of a total of 27 species that entered the ladder, 23 were recorded at the $27 \mathrm{~m}$ height. Only four species remained restricted to the intermediate stretch of the ladder (Box A; Hemisorubim platyrhynchos, Astyanax fasciatum, Astyanax sp. and Leporinus sp.), all of them in low abundance.

The ability of species like Prochilodus lineatus, Pimelodus maculatus and Leporinus spp in overcoming high current velocities and/or ascending fish ladders is also reported by Borghetti et al. (1994) and Godoy (1985).

Although the catches in the two ladder stretches sampled have revealed coincidence between the most abundant and persistent species, the ascent of fishes to the top of the ladder was a more restricted occurrence. The total number of individuals was also inferior in this stretch $(814$ at 10 meters and 647 at 27 meters). These differences must be related to the greater effort required to reach the second sampling point; a further 17 meters in height. In the fish ladder of the hydro power plant of the Tijuco River (25 steps; $78 \mathrm{~m}$ long and 10.8 $\mathrm{m}$ height) only $15 \%$ of the species entering the ladder reached its top, corresponding to barely $2 \%$ of the number of sampled individuals (Godinho et al., 1991).

Considering that the restrictions to some migratory species, such as the large pimelodids, can be overcome by altering the scale used in the construction, the hydraulic model of the experimental fish ladder developed at Itaipu proved a moderate efficient in the attraction and satisfactory in the ascent of fishes.

It should be stressed, however, that fish ladders do not constitute a solution that can be applied to all the problems generated by impoundments to the populations of neotropical migratory fishes. Due to the characteristics of the life cycles of these species, the ladders would be valid instrument for assuring the genetic heterogeneity of the upstream stocks, by re-establishing the contact between subpopulations isolated by the damming (Agostinho et al, 2002). This, however, will only be effective while relevant stretches of the river upstream remain free and preserved.

\section{RESUMO}

A seleção específica de uma escada de peixes do tipo sequiência de tanques, com passagem de fundo (tipo weir and orifice), na barragem da hidrelétrica de Itaipu (rio Paraná), foi avaliada através de amostragens no rio a jusante (amostragem trimestral em 1997) e em dois pontos ao longo da escada (10 e $27 \mathrm{~m}$ de altura; nov/94 a jan/97 e nov/94 a fev/97, respectivamente). Das 65 espécies registradas no rio imediatamente a jusante da barragem, 27 foram capturadas na escada. As espécies com maior densidade na escada, em sua maioria migradoras, tiveram abundância moderada ou baixa a jusante. Entre as mais abundantes a jusante, apenas uma, não migradora, foi registrada na escada. A escada apresentou seleção negativa aos grandes pimelodídeos migradores que pode ser superada com a ampliação na escala do projeto. As amostragens evidenciaram baixa seletividade específica ao longo da escada, sendo seu modelo 
hidráulico satisfatório na atração e eficiente na ascensão de peixes.

\section{REFERENCES}

Agostinho, A. A. (1993), Pesquisas, monitoramento e manejo da fauna aquática em empreendimentos hidrelétricos. Paper presented at Seminário sobre fauna aquática e o Setor Elétrico Brasileiro. Caderno 1, 38-59.

Agostinho, A. A.; Ambrósio, A. M.; Ferreira, V. S.; Minte-Vera, C. V.; Oliveira, E. F.; Okada, E. K. and Suzuki, H. I. (1999), Reservatório de Itaipu: aspectos biológicos e socioeconômicos da pesca. Maringá : Universidade Estadual de Maringá. Núcleo de Pesquisas em Limnologia, Ictiologia e Aquicultura. Technical Report. 237 pp.

Agostinho, A. A.; Thomaz, S. M.; Minte-Vera, C. V. and Winemiller, K. O. (2000), Biodiversity in the high Paraná river floodplain. In: Gopal, B.; Junk, W. J. and Davis, J. A. (eds.). Biodiversity in wetlands: assessment, function and conservation. Leiden : Backhuys Publisher. pp. 89-118.

Agostinho, A. A.; Gomes, L. C. and Fernandez, D. R., (2002) Fish ladders as an instrument for the conservation and management of fishing resources in Brazil. Regulated River: Research and Management, 18 : (3), 299-306.

Borghetti, J. R.; Chena, D. P. and Nogueira, S. V. G. (1993), Installation of a fish migration channel for spawning at the Itaipu hydroelectric power station. Regul. Water Power and Dam Construction, 5, 24-25.

Borghetti, J. R.; Nogueira, V. S. G.; Borghetti, N. R. B. and Canzi, C. (1994), Short Communication - The fish ladder at the Itaipu Binational hydroelectric complex on the Paraná river, Brazil. Regulated Rivers: Research and Management, 9, 129-130.

Britski, A. (1994), As bacias hidrográficas e a preservação da biodiversidade. Paper presented at Seminário sobre fauna aquática e o Setor Elétrico Brasileiro. Caderno 6, 30-37.

Chao, A. (1987), Estimating the population size for capture-recapture data with unequal catchability. Biometrics, 43, 783-791.

Clay, C. H. (1993), Design of Fishways and Other Fish Facilities. Boca Raton : Lewis Publishers.

Fernandez, D. R. and Oro, E. (1996), Variações diuturnas na escada de peixes do projeto experimental canal de migração para desova da Itaipu Binacional. Paper presented at 3. Congresso de Ecologia do Brasil, 10-15 October, Brasília.

Godinho, H. P.; Godinho,A. L.; Formagio, P. S. and Torquato, V. C. (1991), Fish ladder efficiency in a southeastern Brazilian river. Revista Ciência $e$ Cultura, 43, 63-67.
Godoy, M. P. (1985), Aqüicultura: atividade multidisciplinar. Escadas e outras facilidades para passagens de peixes. Florianópolis : Estações de piscicultura. Eletrosul. 77 pp.

Haro, A.; Odeh, M.; Castro-Santos, T. and Noreika, J. (1999), Effect of slope and headpond on passage of American shad and blueback herring through simple Denil and deepened Alaska steeppass fishways. North American Journal of Fisheries Management, 19, 51-58.

Hill, M. O. and Gauch, H. G. (1980), Detrended correspondence analysis: in improved ordination technique. Vegetatio, 42, 47-58.

Larinier, M. (1998), Upstream and downstream fish passage experience in France. In: Jungwirth, M.; Schumtz, S. and Weiss, S. (eds.). Fish Migration and Fish Bypasses. Vienna : Fishing News Books. pp. 127-170.

Martins, S. L. (2.000), Sistemas para transposição de peixes. Dissertação (Mestrado), Escola Politécnica da Universidade de São Paulo, Brasil. 170 pp.

Oldani, N.; Minotti, P.; Rodriguez, R.; Delfino, R. and Baigun, C. (2001), Incidencia de factores ambientales en la abundancia y distribuición de peces del rio Paraná y su relación con los sistemas de transferencia de la represa de Yacyretá. Natura Neotropicalis, 32, 41-48

Peter, A. (1998), Interruption of the river continuum by barriers and consequences for migratory fishes. In: M. Jungwirth; S. Schumtz and S. Weiss (eds.) Fish Migration and Fish Bypasses. Vienna : Fishing News Books. pp. 99- 112.

Quirós, R. (1988), Structures assisting migrations of fish other than salmonids: Latin America. FAOCOPESCAL Tech. Doc., 5, 1-50.

Schwalme, K; Mackay, W. C. and Lindner, D. (1985), Suitability of vertical slot and Denil fishways for passing north-temperate nonsalmonid fish. Canadian Journal of Fisheries Aquatic Science, 42, 1815-1822.

Williams, J. G. (1998), Fish passage in Columbia river, USA and its tributaries: problems and solutions. In: Jungwirth, M.; Schumtz, S. and Weiss, S. (eds.). Fish Migration and Fish Bypasses. Vienna : Fishing News Books. pp. 180-191. 